Tomasevic, J. A., and J. M. Marzluff. 2020. Roosting, reproduction, and survivorship of Pileated Woodpeckers (Dryocopus pileatus) in a suburban setting. Avian Conservation and Ecology 15(1):13. https://doi.org/10.5751/ACE-01547-150113

Copyright (C) 2020 by the author(s). Published here under license by the Resilience Alliance.

Research Paper

\title{
Roosting, reproduction, and survivorship of Pileated Woodpeckers (Dryocopus pileatus) in a suburban setting
}

\author{
Jorge A. Tomasevic ${ }^{1,2}$ and John M. Marzluff ${ }^{2}$ \\ ${ }^{1}$ Centro de Humedales Rio Cruces, Universidad Austral de Chile, Valdivia, Chile, ${ }^{2}$ School of Environmental and Forest Sciences, \\ University of Washington, Seattle, WA USA
}

\begin{abstract}
Urban areas are rapidly expanding and natural habitats are being transformed changing the face of the local biota and the resources available for it. We studied how a purported sensitive species, the Pileated Woodpecker (Dryocopus pileatus), breeds and survives in response to rapid and extensive land cover change as urbanization reduces and potentially isolates forest. From 2009 to 2013, we used radio-telemetry to find woodpecker nests and roost sites, and recorded nest success and adult survivorship at suburban sites in the greater Seattle area, Washington. We found 14 nests and 17 confirmed roost sites. Nests were mostly placed on dead trees or dead branches of trees, primarily on red alder (Alnus rubra) of smaller size than those reported for natural sites. The average productivity of the nests was 2.0 young and most nests (13/14) fledged at least one young. Annual adult survivorship varied across years, but the average $(83.0 \%)$ was higher than what has been reported for nearby natural sites of the Pacific Northwest. Our results suggest that important components of woodpecker fitness in suburban areas may be as good or better than in natural nearby areas. Therefore, suburban forest mosaics can complement conservation in protected areas. Appreciating the importance of human-dominated lands may result on a more integrated view of the urban-wildland gradient and its role on the conservation of the natural world.
\end{abstract}

\section{Dortoir, reproduction et survie du Grand Pic (Dryocopus pileatus) en milieu périurbain}

RÉSUMÉ. Les milieux urbains prennent rapidement de l'expansion et les milieux naturels s'en trouvent transformés, modifiant du même coup le biote local et ses ressources. Nous avons étudié de quelle façon une espèce supposément sensible, le Grand Pic (Dryocopus pileatus), se reproduit et survie malgré le changement rapide et à grande étendue de l'affectation des terres, considérant que l'urbanisation réduit et isole possiblement les forêts. De 2009 à 2013, nous avons trouvé des nids et des dortoirs de pics au moyen de la radio-télémétrie, et avons noté le succès de nidification et la survie adulte dans des sites périurbains de la région métropolitaine de Seattle, Washington. Nous avons trouvé 14 nids et 17 dortoirs confirmés. Les nids étaient généralement situés dans des arbres morts ou des branches mortes d'arbres, surtout dans des aulnes rouges (Alnus rubra) de tailles plus petites que celles ayant été rapportées pour les sites en milieu naturel. La productivité moyenne des nids était de 2.0 jeunes et dans la plupart des nids (13/14), au moins un jeune a pris son envol. La survie annuelle des adultes a varié au cours des années, mais la survie moyenne (83.0\%) était plus élevée que celle qui a été rapportée dans des sites naturels environnant du Nord-Ouest du Pacifique. Nos résultats indiquent que certaines composantes importantes de la valeur adaptative (fitness) des pics en milieu périurbain sont peut-être aussi bonnes voire meilleures que celles que les pics présentent dans des endroits naturels voisins. Ainsi, des mosaïques de forêts périurbaines peuvent compléter les mesures de conservation dans les aires protégées. En reconnaissant l'importante des terres dominées par l'homme, une perspective plus intégrée du gradient urbainnaturel et de son rôle dans la conservation de la nature planétaire pourrait s'ouvrir.

Key Words: breeding; fitness; Picidae; reproduction; survivorship

\section{INTRODUCTION}

The world's population, especially that of urban areas, continues to grow (United Nations 2008, 2019). The addition of nearly 67 million people to urban areas each year (Pickett et al. 2011) increases the footprint of cities and their suburban areas throughout the world (Blair 2004, Cohen 2006, Aronson et al. 2014). The expansion and sprawl of cities affects plant and animal communities by changing vegetation composition, quantity and structure (Donnelly and Marzluff 2006), microclimatic conditions, biotic interactions (Chace and Walsh 2006, Endlicher 2011), and connectivity within and between surrounding natural areas (Fernández-Juricic 2000). Once an area is developed it rarely goes back to its natural state (Marzluff and Ewing 2001, McKinney 2006), although native vegetation may be retained or incorporated by developers, planners, managers, or residents (Aronson et al. 2014). This, in conjunction with factors such as altered disturbance regimes (Chace and Walsh 2006) and supplemental food and water (Robb et al. 2008, Clucas and Marzluff 2011), creates novel conditions for wildlife and plants that bring challenges and opportunities that will favor species with the ability to adapt to them (Kowarik 2011) and extirpate those that cannot (Marzluff 2014).

Many woodpecker species require specific habitat features and, as with many other cavity nesting birds, their presence and abundance may be limited by the availability of snags (standing dead trees) for foraging, roosting, and nesting (Newton 1998, Bull and Jackson 2011). Because snags are often removed when natural 
forests are cleared for housing developments (Blewett and Marzluff 2005, Blair and Johnson 2008, Davis et al. 2014, LaMontagne et al. 2015), urbanization may lead to declines in woodpecker populations (Blair 1996). These declines may affect other species that are connected to the resources that woodpeckers provide (Martin and Eadie 1999, Aubry and Raley 2002a, Tomasevic and Marzluff 2017) potentially amplifying the negative effects onto the biological communities present in areas that undergo urban development (Morrison and Chapman 2005).

Puzzled by the question of whether a large woodpecker species with such influence in the ecological community may be able to adapt and succeed in a novel environment, we studied the survivorship and reproduction of the Pileated Woodpecker (Dryocopus pileatus) in suburban areas around Seattle, Washington, USA. Being a forest species with preference for mature and old-growth forest (Bull and Jackson 2011), we expected this species to be negatively affected by habitat changes caused by urbanization. However, there is evidence that this species is adaptable and able to take advantage of these areas instead, but little information on nest success, survivorship, and other aspects of fitness for this species on suburban areas. The main objective of this paper is to document such aspects in suburban areas of Seattle, Washington.

\section{METHODS}

\section{Focal species}

The Pileated Woodpecker is a forest bird, typically associated with late-successional or mature coniferous or deciduous forest, which uses younger forests with scattered large trees (Bull and Jackson 2011) and forested suburban areas (Hoyt 1957, Blewett and Marzluff 2005, Erskine 2008, Diamond et al. 2020). It normally requires large areas of suitable habitat and it has been documented to be sensitive to habitat loss, fragmentation, and degradation in natural areas (Bull et al. 2007, Bull and Jackson 2011) as well as in suburban areas, where the abundance of this species is positively associated with the percentage of forest remaining (Blewett and Marzluff 2005).

Pileated Woodpeckers can be found in urban and suburban areas (Blewett and Marzluff 2005, Erskine 2008), although their densities tend to be low (Beissinger and Osborne 1982, Blewett and Marzluff 2005). In fact, Pileated Woodpecker density is positively associated with the percentage of forest remaining (at a $1 \mathrm{~km}^{2}$ scale) in urbanizing landscapes, and their densities in suburban areas (forested and built areas combined) can be up to eight times lower than in natural areas (Blewett and Marzluff 2005). To our knowledge, there is no information on suburban woodpecker reproductive success, roost use, and survivorship.

\section{Study area}

We conducted our study in three main areas in the vicinity of Seattle, Washington, USA, where we detected and successfully trapped Pileated Woodpeckers. These areas were part of a larger study described elsewhere (Marzluff et al. 2016) that were used to research the effects of urbanization on birds, including cavitynesting birds (Blewett and Marzluff 2005). The northern area was close to the town of Maltby, Washington, the central area was close to Redmond, Washington, and the southern area was close to Bellevue, Washington (Appendix 1). These three areas were similar in terms of deciduous forest cover, while Redmond had less coniferous forest and more medium and heavy urban cover (see more details in Tomasevic and Marzluff 2018a,b). The lowlands of western Washington are naturally mostly forested lands. The climax stage of these forests is dominated by coniferous species, such as western hemlock (Tsuga heterophylla) and western red cedar (Thuja plicata) with presence of Douglas fir (Pseudotsuga menziesii) as subclimax species (Franklin and Dyrness 1988). Before European settlement, hardwoods were not common in this zone, except on recently disturbed or riparian areas, where big leaf maple (Acer macrophyllum), red alder (Alnus rubra), and black cottonwood (Populus trichocarpa) were the most prevalent species (Franklin and Dyrness 1988). After a century and a half of habitat modification (Cuo et al. 2009) and the accelerated expansion of urban and suburban areas in the region (MacLean and Bolsinger 1997, Alberti et al. 2004), the amount, composition, and structure of the forest has changed dramatically (Donnelly and Marzluff 2006), where mostly early successional species (mostly the hardwoods mentioned above and Douglas fir) dominate suburban forests.

\section{Radiotelemetry}

We trapped woodpeckers year-round using mist-nets and playback (York et al. 1998). We used a hand-made Styrofoam decoy (painted with the colors and patterns of a perching Pileated Woodpecker) with red feathers attached to its head to increase responsiveness to the decoy. We also trapped close to suet feeders (present in neighborhoods at the study sites) during fall and winter when the birds did not show a strong response to the playback. Once we trapped a bird, we banded it, fitted a radio transmitter (model A1250 from Advanced Telemetry Systems, Isanti, MN; expected life 12 months) using a Teflon ${ }^{\mathrm{TM}}$ backpack harness modified from Buehler et al. (1995). We used 2-mm wide copper rings to secure the harness in lieu of sewing. Transmitter plus harness weighed $11.5 \mathrm{~g}$, which is less than $5 \%$ of the weight of an adult Pileated Woodpecker. We released the birds back to the same area where we captured them. Our processing time was typically 30-45 minutes. We used an R-1000 telemetry receiver (Communications Specialists, Orange, CA) and a hand-held, 3element, Yagi antenna to relocate each radio-tagged bird opportunistically, aiming to have at least one location per week. While handling each individual bird, we recorded its sex, weight, and other morphometric information reported elsewhere (Tomasevic 2017). We monitored the birds after release for 10-15 minutes and checked on them the following day to verify that there were no problems with the transmitter or the newly tagged bird.

We tracked the birds year-round and recorded the relocations of each bird on custom-made maps for each site based on current aerial photographs available online (Google Maps, Google Inc., Mountain View, CA) at approximately 1:10,000 scale. We used mostly visual confirmation of the location of the birds, but in cases when that was not possible, we estimated their location using triangulation to the telemetry signal or the calls made by the birds. In cases when the location was not obvious on the map, we used GPS to mark a reference point and measured the distance and bearing to the woodpecker location with a laser rangefinder (TruPulse 360B, Laser Technologies Inc., Centennial, CO). We 
then entered all the locations into GIS using ArcGIS (9.x and 10. $\mathrm{x}, \mathrm{ESRI}$, Redlands, CA). We estimated home ranges using fixedkernel density estimation (Worton 1989), space use with utilization distribution functions (Marzluff et al. 2004), and characterized the land cover types encompassed within each home range based on $30 \mathrm{~m}$ Landsat TM satellite imagery classified onto 14 land cover types (Hepinstall et al. 2008), as is presented elsewhere (Tomasevic and Marzluff 2018a, b).

\section{Breeding success, productivity, and survivorship}

To assess some habitat elements that may be important for this species' fitness, we described nests and roost sites. We followed tagged birds to their roosts and nests. We found roosts at dusk or before dawn. Once we detected them, we recorded DBH (with a DBH tape), height (with a laser rangefinder described above), tree species, type of substrate (live tree, snag, or dead portion of a live tree), signs of Pileated Woodpecker foraging, and signs of fungi infection of the substrate. We also quantified the distance of nests and roosts to the nearest street and building to assess their proximity to human presence.

We assessed the reproductive output (number of chicks fledged) and annual survivorship of radio-tagged birds. To assess reproductive output, we recorded the number of offspring that fledged from each nest $(n=14)$, or when we could not find their nests $(n=4)$, we recorded presence or absence of fledglings accompanying adults during the breeding season. Given our experience, fledglings in distinct plumage (Pyle 1997) stayed with their parents for at least three months, thereby providing a good measure of nesting success. We considered a nest to be successful if they fledged at least one young.

We estimated annual survivorship using the Kaplan-Meier procedure modified to include staggered entry of animals (Pollock et al. 1989). Since we started the study on May 2009, our annual survivorship estimates are from May to May (from one breeding season to the next). We also related survivorship to characteristics of the birds and their home range (specifically area of different land cover types or the percentage they represent) using simple Cox proportional hazard regression (Fox and Weisberg 2011). We performed analyses using the survival package (ver. 2.43-3, Therneau 2018) in R (ver. 3.5.3, R Core Team 2019). We present statistics as mean \pm standard error (SE) throughout the text, unless otherwise noted.

\section{RESULTS}

We trapped 16 adult Pileated Woodpeckers (nine males and seven females) between 2009 and 2012. We captured three adult males in each of the study areas, but the number of females varied among sites (four in Maltby, two in Redmond, and one in Bellevue). We captured both the male and female of three breeding pairs (two pairs in consecutive years, and one pair in the same year). On one occasion, we trapped a male and female on the same area, but they did not breed together. We radio-tracked these birds for an average of $10.8 \pm 1.17$ months (11/16 were followed for more than 11.5 months) and obtained an average of $78 \pm 12$ locations per bird.

We found 14 nests over the span of this study. Pileated Woodpeckers nested in snags $(84.6 \%, n=11)$ of different tree species or in dead branches on live big leaf maple trees $(15.4 \%, n$ $=2$ ). Most nests were located in red alder snags $(69.23 \%, n=9)$, although dead black cottonwoods $(n=1)$ or dead Douglas-firs $(n=1)$ were occasionally used. On average, snags were $17.86 \pm 1.76$ $\mathrm{m}$ in height and nests were placed in the upper portion of the snag $(69.3 \%$ of the height) at $12.4 \pm 2.8 \mathrm{~m}$. The nests in trees were at similar height to the ones in snags $(\sim 14 \mathrm{~m})$, although because the trees were taller than snags, they were approximately in the middle of the tree ( $48 \%$ of the total height). Most of the snags presented either previous foraging signs by Pileated or other woodpeckers $(71.43 \%)$ or had signs of fungal infection $(50 \%)$, although they were not foraging snags (only dedicated to foraging). Only a few of these snags had other nest cavities present $(37.5 \%)$. The average $\mathrm{DBH}$ of the nesting substrates was $46.25 \pm 2.99 \mathrm{~cm}(n=8)$. The nests were located mostly in forested areas among housing developments, e.g., green belts or parks. On average, nests were located $146 \pm 40 \mathrm{~m}(n=13)$ away from the nearest street and 128 $\pm 36 \mathrm{~m}(n=13)$ from the nearest building, with the extreme example of a nest located on a snag on the backyard of a house (merely $6 \mathrm{~m}$ away from the house) or another nest located $12 \mathrm{~m}$ from a street (parking lot).

We located 17 roosts that were shared amongst members of the pair or family groups. Pileated Woodpeckers used multiple roost sites within their territories (between 1 and 5, 2.83 \pm 0.75 ) and reused roosts often (we did not follow their roost use every day to provide accurate data on roost reuse), although we did not record more than one bird sharing the roosting location on the same night. Woodpeckers roosted in snags and trees $(52.9 \%$ vs $47.1 \%$, respectively), but they only roosted in red alders or big leaf maples. Red alder snags and live big leaf maple trees (with cavities or crevices on the trunk) had the same number of roosts $(6 / 17$ each, $35.3 \%$ ), with fewer in big leaf maple snags $(17.65 \%$ of the roost sites; $n=3$ ). Live red alders accounted for the remaining $11.76 \%$ of the roost sites $(n=2)$. Roosting cavities were placed in snags at an average of $13.2 \pm 4.8 \mathrm{~m}$ in height, which represented $83.9 \%$ of the snag height (on average). Roost sites placed in live trees were at an average of $8.8 \pm 1.1 \mathrm{~m}$, which represents $43.1 \%$ of the trees height. The average DBH of the roosting substrates was $49.6 \pm 6.1 \mathrm{~cm}(n=10)$. Similar to what we described for nest sites, roost sites were in close proximity to human structures. On average, they were $63.9 \pm 12.5 \mathrm{~m}$ away from buildings and 97.5 $\pm 13.8 \mathrm{~m}$ away from streets.

\section{Breeding success, productivity, and survivorship}

Nearly every nest we located succeeded in fledging at least one young ( $n=13$ of 14 nests; $92.8 \%$ ). The one nest that failed was because an unknown predator killed the female before she laid eggs (we found the carcass in a burrow right under the nesting tree, but it was completely destroyed). At 10 nests where we obtained accurate fledgling counts, pairs fledged a mean of 2.00 $( \pm 0.69)$ nestlings. We confirmed the production of 27 young fledged by 11 breeding pairs on 16 breeding attempts from 2009 to 2013 . Over the five breeding seasons, we documented that only three adults on different territories (two males and one female) failed to breed at all. One of these males was apparently paired, but never bred. The other two birds apparently were not paired. We found no relationship between the average number of chicks fledged and landscape characteristics of the home ranges (in terms of area or percentage of each land cover type; Appendix 2). 
We recorded five deaths among the individuals we followed on this study (three males and two females) with adult annual survivorship (of males and females combined) varying among years (range: $62.5 \%-100 \%$, average: $83 \% \pm 0.08 \%$; Fig 1 ). We found that survivorship increased over the length of our study (Cox Proportional Hazards Model, coef $=-1.26, z_{15}=-2.18$, $\mathrm{df}$ $=15, P=0.03$, hazard ratio of 0.28 , CI95\% [0.09, 0.88]). Adult annual survivorship rate (of males and females) was not influenced by bird mass (Cox Proportional Hazards Model, exp (coef) $=0.994, z_{15}=-0.34, P=0.74$ ) or sex (Cox Proportional Hazards Model, $\exp ($ coef $\left.)=0.964, z_{15}=-0.04, P=0.97\right)$. We found no relationship between survivorship and the size or percentage of different land cover types on male woodpeckers' home ranges. Even for commonly and rarely used land covers (coniferous forest and heavy urban, respectively; Tomasevic and Marzluff 2018b), we found no significant effect of habitat on survivorship. For example, males that concentrated their home ranges in coniferous forests (Cox Proportional Hazards Model, coef $=0.06, z_{8}=1.39, P=0.17$ ) or the ones that used heavy urban land cover (Cox Proportional Hazards Model, $\exp ($ coef $)=0.85$, $z_{8}=-1.23, P=0.22$ ) showed opposite trends on survivorship, although none of them were statistically significant.

Fig. 1. Annual survivorship curves for Pileated Woodpeckers (Dryocopus pileatus) in a suburban setting between 2009 and 2014. Note that each year is expressed in weeks and all of them start mid-May until mid-May the following calendar year.

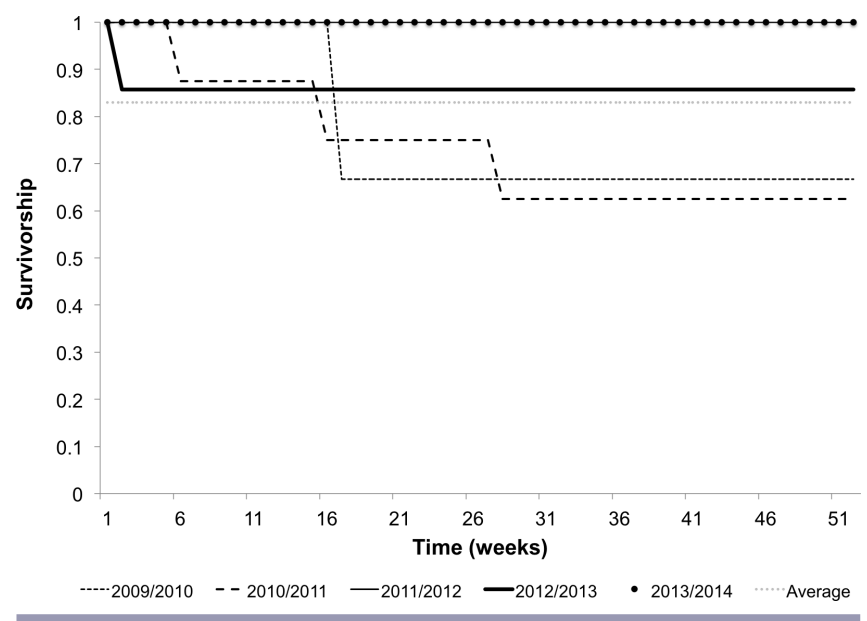

\section{DISCUSSION}

Pileated Woodpeckers successfully used the forested areas of suburban Seattle, despite the lack of snags as large as the ones found in natural areas close to our study sites (Blewett and Marzluff 2005), which are normally thought to be critical for this species. For example, Pileated Woodpeckers were only found nesting on trees and snag between 65 and $154 \mathrm{~cm} \mathrm{DBH} \mathrm{(mean} \mathrm{=}$ $101.2 \mathrm{~cm}$ ) in western Washington (Aubry and Raley 2002a) or on snags that averaged $82 \mathrm{~cm}$ on southeastern Vancouver Island, British Columbia (Hartwig et al. 2004). And although there is variability on the size of nest trees or snags reported along the distribution range of this species (Bull and Meslow 1977, Mellen et al. 1992, Aubry and Raley 2002a, Hartwig et al. 2004, Bull and Jackson 2011), we found that the nests on our sites were placed on snags that were significantly smaller. This trend is similar to the use of palm tree snags in urban areas reported in Miami, Florida (Diamond et al. 2020), where woodpeckers used snags that averaged $28.5 \pm 9.9 \mathrm{~cm}$, which may be considered small diameter for nest substrates for this species compared to natural areas. Bonar (2001) reported no relationship between tree size and nest placement height, which is similar to what we observed.

Roost sites are important to woodpeckers. Pileated Woodpeckers have been reported to select large trees for their roost sites (Bull et al. 1992, Aubry and Raley 2002b) and it is known that they use different roost sites throughout the year. We observed suburban woodpeckers use between one and five roost sites. We consider this an underestimate because other studies report between four and seven roost sites (Bull et al. 1992). We observed our birds roosting alone, contrary to the report of other studies that show that sometimes Pileated Woodpeckers roost in pairs or small groups (McClelland and McClelland 1999, Aubry and Raley $2002 b$ ). However, we found that the birds in our areas did not use especially large trees, which may reflect the ability of this species to adapt to the lack of their preferred habitat trees to meet their requirements.

Our results suggest that fitness of suburban Pileated Woodpeckers in our area may be as high or higher than in nearby natural areas. The productivity of suburban Pileated Woodpeckers was lower than that reported throughout its wide range (2.00 vs. 3.83 ; Bull and Jackson 2011), but similar to that reported for the Pacific Northwest (productivity: 2.26 young/nest, $t$-test, $t_{1}=-0.54, P=$ 0.30 ; breeding success: $83 \%$; Bull and Meslow 1988). Mean annual adult survival in our sites was not significantly different from that reported in other studies on natural sites on the Pacific Northwest $\left(X_{3}^{2}=1.6, P=0.34,50 \%\right.$ in the Olympic Peninsula, Aubry and Raley, as cited in Bull and Jackson 2011 (as personal communication), $64 \%$ on color-banded individuals in NE Oregon, Bull and Meslow 1988, and $47 \%$ on radio-tagged individuals in NE Oregon, Bull 2001). We also found higher survivorship than what Bonar (2001) reported for radio-tagged Pileated Woodpeckers at the Alberta foothills in Canada (between 56.3\% and $68.8 \%$ ). In fact, the survivorship we observed provides evidence that this species may be subsidized by humans in suburban areas, even with the presence of native raptors that may also benefit from human subsidies, such as bird feeders. Survivorship was much higher than has been reported for other woodpecker species in natural areas (Wiebe 2006). This pattern may be hard to explain given the rich presence of avian predators in the area (Rullman and Marzluff 2014), a pattern described for other areas as well (Chace and Walsh 2006). However, we observed several encounters between Pileated Woodpeckers and Cooper's Hawks (Accipiter cooperii) where the raptor was unsuccessful in preying upon the woodpecker. Pileated Woodpeckers may also benefit from the use of human subsidies such as bird feeders, which may provide a more stable food supply year-round (Robb et al. 2008). The combined effect of these factors on survival, productivity, and behavior deserves further study.

This study highlights the importance of suburban areas for wildlife conservation, where everyday activities merge with the enjoyment of the natural world (Marzluff 2002). Suburban areas will never replace natural areas for species and ecosystem conservation, nor for ecosystem services provision, but they can help us expand our conservation toolkit on this rapidly changing and increasingly endangered world. 
Responses to this article can be read online at: http://www.ace-eco.org/issues/responses.php/1547

\begin{abstract}
Acknowledgments:
We thank J. Bakker, J. J. Lawler, M. G. Raphael, J. Tewksbury, R. B. Huey, and E. J. Theobald for their invaluable comments at different stages of the development of this manuscript. We thank $J$. Ladd, K. Holt, A. Gale-Seixeiro, S. Shriver, D. Griffith, and J. Rettig kindly for allowing us to trap Pileated Woodpeckers on their property. We thank S. Williams, L. Farwell, S. Wang, L. Walker, R. Forbush, I. Palmquist, J. Granger, K. Richardson, F. Stevick, C. O'Neil, J. DeLap, J. Bragg, and many others for their assistance in the field. We also thank S. Williams, L. Farwell, P. Hodum, and N. Hamel who helped with transportation to the field sites. We also thank the reviews and comments provided by peers and the editors of this journal.
\end{abstract}

\section{LITERATURE CITED}

Alberti, M., R. Weeks, and S. Coe. 2004. Urban land-cover change analysis in central Puget Sound. Photogrammetric Engineering \& Remote Sensing 9:1043-1052. https://doi.org/10.14358/PERS.70.9.1043

Aronson, M. F., F. A. La Sorte, C. H. Nilon, M. Katti, M. A. Goddard, C. A. Lepczyk, P. S. Warren, N. S. Williams, S. Cilliers, B. Clarkson, C. Dobbs, R. Dolan, M. Hedblom, S. Klotz, J. L. Kooijmans, I. Kühn, I. MacGregor-Fors, M. McDonnell, U. Mörtberg, P. Pyšek, S. Siebert, J. Sushinsky, P. Werner, and M. Winter. 2014. A global analysis of the impacts of urbanization on bird and plant diversity reveals key anthropogenic drivers. Proceedings of the Royal Society of London B: Biological Sciences 281(1780). https://doi.org/10.1098/rspb.2013.3330

Aubry, K. B., and C. M. Raley. 2002a. The Pileated Woodpecker as a keystone habitat modifier in the Pacific Northwest. General Technical Report PSW-GTR-181:257-274. U.S. Forest Service Pacific Northwest Research Station, Olympia, Washington, USA.

Aubry, K. B., and C. M. Raley. 2002b. Selection of nest and roost trees by Pileated Woodpeckers in coastal forests of Washington. Journal of Wildlife Management 66(2):392-406. https://doi. org/10.2307/3803172

Beissinger, S. R., and D. R. Osborne. 1982. Effects of urbanization on avian community organization. Condor 84:75-83. https://doi. org/10.2307/1367825

Blair, R. 2004. The effects of urban sprawl on birds at multiple levels of biological organization. Ecology and Society 9(5):2. https://doi.org/10.5751/ES-00688-090502

Blair, R. B. 1996. Land use and avian species diversity along an urban gradient. Ecological Applications 6:506-519. https://doi. org/10.2307/2269387

Blair, R. B., and E. M. Johnson. 2008. Suburban habitats and their role for birds in the urban-rural habitat network: points of local invasion and extinction? Landscape Ecology 23:1157-1169. https://doi.org/10.1007/s10980-008-9267-y
Blewett, C. M., and J. M. Marzluff. 2005. Effects of urban sprawl on snags and the abundance and productivity of cavity-nesting birds. Condor 107:678-693. https://doi.org/10.1093/condor/107.3.678

Bonar, R. L. 2001. Pileated Woodpecker habitat ecology in the Alberta foothills. Dissertation. University of Alberta, Edmonton, Alberta, Canada. [online] URL: http://www.nlc-bnc.ca/obj/s4/f2/ dsk1/tape2/PQDD_0010/NQ60276.pdf

Buehler, D. A., J. D. Fraser, M. R. Fuller, L. S. McAllister, and J. K. Seegar. 1995. Captive and field-tested radio transmitter attachments for Bald Eagles. Journal of Field Ornithology 66:173-180.

Bull, E. L. 2001. Survivorship of Pileated Woodpeckers in northeastern Oregon. Journal of Field Ornithology 72:131-135. https://doi.org/10.1648/0273-8570-72.1.131

Bull, E. L., R. S. Holthausen, and M. G. Henjum. 1992. Roost trees used by Pileated Woodpeckers in northeastern Oregon. Journal of Wildlife Management 56(4):786-793. https://doi. org/10.2307/3809474

Bull, E. L., and J. A. Jackson. 2011. Pileated Woodpecker (Dryocopus pileatus), version 2.0. In A. F. Poole, editor. The birds of North America. Cornell Lab of Ornithology, Ithaca, New York, USA. https://doi.org/10.2173/bna.148

Bull, E. L., and E. C. Meslow. 1977. Habitat requirements of the Pileated Woodpecker in northeastern Oregon. Journal of Forestry 75:335-337.

Bull, E. L., and E. C. Meslow. 1988. Breeding biology of the Pileated Woodpecker: management implications. Research Note PNW-RN-474. U.S. Forest Service, Pacific Northwest Research Station, Portland, Oregon, USA. https://doi.org/10.2737/PNWRN-474

Bull, E. L., N. Nielsen-Pincus, B. C. Wales, and J. L. Hayes. 2007. The influence of disturbance events on Pileated Woodpeckers in northeastern Oregon. Forest Ecology and Management 243:320-329. https://doi.org/10.1016/j.foreco.2007.03.031

Chace, J. F., and J. J. Walsh. 2006. Urban effects on native avifauna: a review. Landscape and Urban Planning 74:46-69. https://doi.org/10.1016/j.landurbplan.2004.08.007

Clucas, B., and J. M. Marzluff. 2011. Coupled relationships between humans and other organisms in urban areas. Pages 135-147 in J. Niemelä, J. H. Breuste, T. Elmqvist, G. Guntenspergen, P. James, and N. E. McIntyre, editors. Urban ecology: patterns, processes, and applications. Oxford University Press, Oxford, UK. https://doi.org/10.1093/acprof: oso/9780199563562.003.0017

Cohen, B. 2006. Urbanization in developing countries: current trends, future projections, and key challenges for sustainability. Technology in Society 28:63-80. https://doi.org/10.1016/j. techsoc.2005.10.005

Cuo, L., D. P. Lettenmaier, M. Alberti, and J. E. Richey. 2009. Effects of a century of land cover and climate change on the hydrology of the Puget Sound basin. Hydrological Processes 23:907-933. https://doi.org/10.1002/hyp.7228 
Davis, A., R. E. Major, and C. E. Taylor. 2014. Distribution of tree-hollows and hollow preferences by parrots in an urban landscape. Emu 114:295-303. https://doi.org/10.1071/MU13065

Diamond, J. M., M. S. Ross, H. Liu, and J. T. Heinen. 2020. Palm snags are a critical nesting resource for woodpeckers in an urbanized tropical region. Urban Ecosystems 23:67-78. https:// doi.org/10.1007/s11252-019-00899-X

Donnelly, R., and J. M. Marzluff. 2006. Relative importance of habitat quantity, structure, and spatial pattern to birds in urbanizing environments. Urban Ecosystems 9:99-117. https:// doi.org/10.1007/s11252-006-7904-2

Endlicher, W. 2011. Introduction: from urban nature studies to ecosystem services. Pages 1-13 in W. Endlicher, P. Hostert, I. Kowarik, E. Kulke, J. Lossau, J. Marzluff, E. van der Meer, H. Mieg, G. Nützmann, M. Schulz, and G. Wessolek, editors. Perspectives in urban ecology. Springer, Heidelberg, Germany. https://doi.org/10.1007/978-3-642-17731-6_1

Erskine, A. J. 2008. Pileated Woodpeckers, Dryocopus pileatus, foraging in suburban habitats in New Brunswick. Canadian FieldNaturalist 122:226-229. https://doi.org/10.22621/cfn.v122i3.603

Fernández-Juricic, E. 2000. Avifaunal use of wooded streets in an urban landscape. Conservation Biology 14:513-521. https://doi. org/10.1046/j.1523-1739.2000.98600.x

Fox, J., and S. Weisberg. 2011. Cox proportional-hazards regression for survival data in R. Pages 1-20 in An R companion to applied regression. Second edition. SAGE, Los Angeles, California, USA.

Franklin, J. F., and C. T. Dyrness. 1988. Natural vegetation of Oregon and Washington. Oregon State University Press, Corvallis, Oregon, USA.

Hartwig, C. L., D. S. Eastman, and A. S. Harestad. 2004. Characteristics of Pileated Woodpecker (Dryocopus pileatus) cavity trees and their patches on southeastern Vancouver Island, British Columbia, Canada. Forest Ecology and Management 187:225-234. https://doi.org/10.1016/S0378-1127(03)00334-7

Hepinstall, J. A., M. Alberti, and J. M. Marzluff. 2008. Predicting land cover change and avian community responses in rapidly urbanizing environments. Landscape Ecology 23:1257-1276. https://doi.org/10.1007/s10980-008-9296-6

Hoyt, S. F. 1957. The ecology of the Pileated Woodpecker. Ecology 38:246-256. https://doi.org/10.2307/1931683

Kowarik, I. 2011. Novel urban ecosystems, biodiversity, and conservation. Environmental Pollution 159:1974-1983. https://doi. org/10.1016/j.envpol.2011.02.022

LaMontagne, J. M., R. J. Kilgour, E. C. Anderson, and S. Magle. 2015. Tree cavity availability across forest, park, and residential habitats in a highly urban area. Urban Ecosystems 18:151-167. https://doi.org/10.1007/s11252-014-0383-y

MacLean, C. D., and C. L. Bolsinger. 1997. Urban expansion in the forests of the Puget Sound region. Resource Bulletin PNWRB-225. U.S. Forest Service, Pacific Northwest Research Station, Portland, Oregon, USA. https://doi.org/10.2737/PNW-RB-225
Martin, K., and J. M. Eadie. 1999. Nest webs: a community-wide approach to the management and conservation of cavity-nesting forest birds. Forest Ecology and Management 115:243-257. https:// doi.org/10.1016/S0378-1127(98)00403-4

Marzluff, J. M. 2002. Fringe conservation: a call to action. Conservation Biology 16:1175-1176. https://doi.org/10.1046/ j.1523-1739.2002.16501.X

Marzluff, J. M. 2014. Welcome to Subirdia: sharing our neighborhoods with wrens, robins, woodpeckers and other wildlife. Yale University Press, New Haven, Connecticut, USA.

Marzluff, J. M., B. Clucas, M. D. Oleyar, and J. DeLap. 2016. The causal response of avian communities to suburban development: a quasi-experimental, longitudinal study. Urban Ecosystems 19:1597-1621. https://doi.org/10.1007/s11252-015-0483-3

Marzluff, J. M., and K. Ewing. 2001. Restoration of fragmented landscapes for the conservation of birds: a general framework and specific recommendations for urbanizing landscapes. Restoration Ecology 9:280-292. https://doi.org/10.1046/ j.1526-100x.2001.009003280.x

Marzluff, J. M., J. J. Millspaugh, P. Hurvitz, and M. S. Handcock. 2004. Relating resources to a probabilistic measure of space use: forest fragments and Steller's Jays. Ecology 85:1411-1427. https:// doi.org/10.1890/03-0114

McClelland, B. R., and P. T. McClelland. 1999. Pileated Woodpecker nest and roost trees in Montana: links with oldgrowth and forest "health." Wildlife Society Bulletin 27 (3):846-857.

McKinney, M. L. 2006. Urbanization as a major cause of biotic homogenization. Biological Conservation 127:247-260. https:// doi.org/10.1016/j.biocon.2005.09.005

Mellen, T. K., E. C. Meslow, and R. W. Mannan. 1992. Summertime home range and habitat use of Pileated Woodpeckers in western Oregon. Journal of Wildlife Management 56:96-103. https://doi.org/10.2307/3808796

Morrison, J. L., and W. C. Chapman. 2005. Can urban parks provide habitat for woodpeckers? Northeastern Naturalist 12:253-262. https://doi.org/10.1656/1092-6194(2005)012[0253: cupphf]2.0.co;2

Newton, I. 1998. Population limitation in birds. Academic, San Diego, California, USA.

Pickett, S. T. A., M. L. Cadenasso, J. M. Grove, C. G. Boone, P. M. Groffman, E. Irwin, S. S. Kaushal, V. Marshall, B. P. McGrath, C. H. Nilon, et al. 2011. Urban ecological systems: scientific foundations and a decade of progress. Journal of Environmental Management 92:331-362. https://doi.org/10.1016/j.jenvman.2010.08.022

Pollock, K. H., S. R. Winterstein, C. M. Bunck, and P. D. Curtis. 1989. Survival analysis in telemetry studies: the staggered entry design. Journal of Wildlife Management 53:7-15. https://doi. org/10.2307/3801296

Pyle, P. 1997. Identification guide to North American birds. Part I. Columbidae to Ploceidae. Slate Creek Press, Bolinas, California, USA. 
R Core Team. 2019. R: A language and environment for statistical computing. R Foundation for Statistical Computing, Vienna, Austria. [online] URL: http://CRAN.R-project.org

Robb, G. N., R. A. McDonald, D. E. Chamberlain, and S. Bearhop. 2008. Food for thought: supplementary feeding as a driver of ecological change in avian populations. Frontiers in Ecology and the Environment 6:476-484. https://doi.org/10.1890/060152

Rullman, S., and J. M. Marzluff. 2014. Raptor presence along an urban-wildland gradient: influences of prey abundance and land cover. Journal of Raptor Research 48:257-272. https://doi. org/10.3356/JRR-13-32.1

Therneau, T. 2018. A package for survival analysis. [online] URL: http://CRAN.R-project.org/package=survival

Tomasevic, J. A. 2017. Cavity-nesting bird interactions in the urbansuburban gradient. Dissertation. University of Washington, Seattle, Washington, USA.

Tomasevic, J. A., and J. M. Marzluff. 2017. Cavity nesting birds along an urban-wildland gradient: is human facilitation structuring the bird community? Urban Ecosystems 20:435-448. https://doi.org/10.1007/s11252-016-0605-6

Tomasevic, J. A., and J. M. Marzluff. 2018a. Space use of suburban Pileated Woodpeckers (Dryocopus pileatus): insights on the relationship between home range, core areas, and territory. Oecologia 187:15-23. https://doi.org/10.1007/s00442-018-4135-1

Tomasevic, J. A., and J. M. Marzluff. 2018b. Use of suburban landscapes by the Pileated Woodpecker (Dryocopus pileatus). Condor 120:727-738. https://doi.org/10.1650/condor-17-171.1

United Nations. 2008. World urbanization prospects: the 2007 revision. Highlights. United Nations, Department of Economic and Social Affair/Population Division, New York, New York, USA.

United Nations. 2019. World population prospects. Highlights, 2019 revision. United Nations, Department of Economic and Social Affairs, Population Division, New York, New York, USA.

Wiebe, K. L. 2006. A review of adult survival rates in woodpeckers. Annales Zoologici Fennici 43:112-117.

Worton, B. J. 1989. Kernel methods for estimating the utilization distribution in home-range studies. Ecology 70:164-168. https:// doi.org/10.2307/1938423

York, D. L., J. E. Davis Jr, J. L. Cummings, and E. A. Wilson. 1998. Pileated Woodpecker capture using a mist net and taped call. North American Bird Bander 23:81-82.

Editor-in-Chief: Alexander L.Bond Subject Editor: Jean-Pierre L.Savard

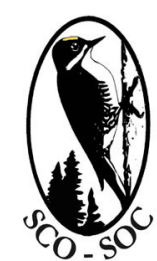

Sponsored by the Society of Canadian Ornithologists and Birds Canada

Parrainée par la Société des ornithologistes du Canada et Oiseaux Canada

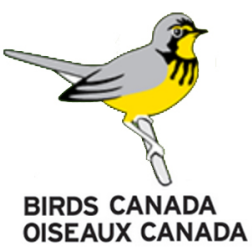


Appendix 1. Study area on the Greater Seattle, WA, highlighting the 3 main areas where we conducted this study. Land cover types are indicated according to Alberti et al. (2006).

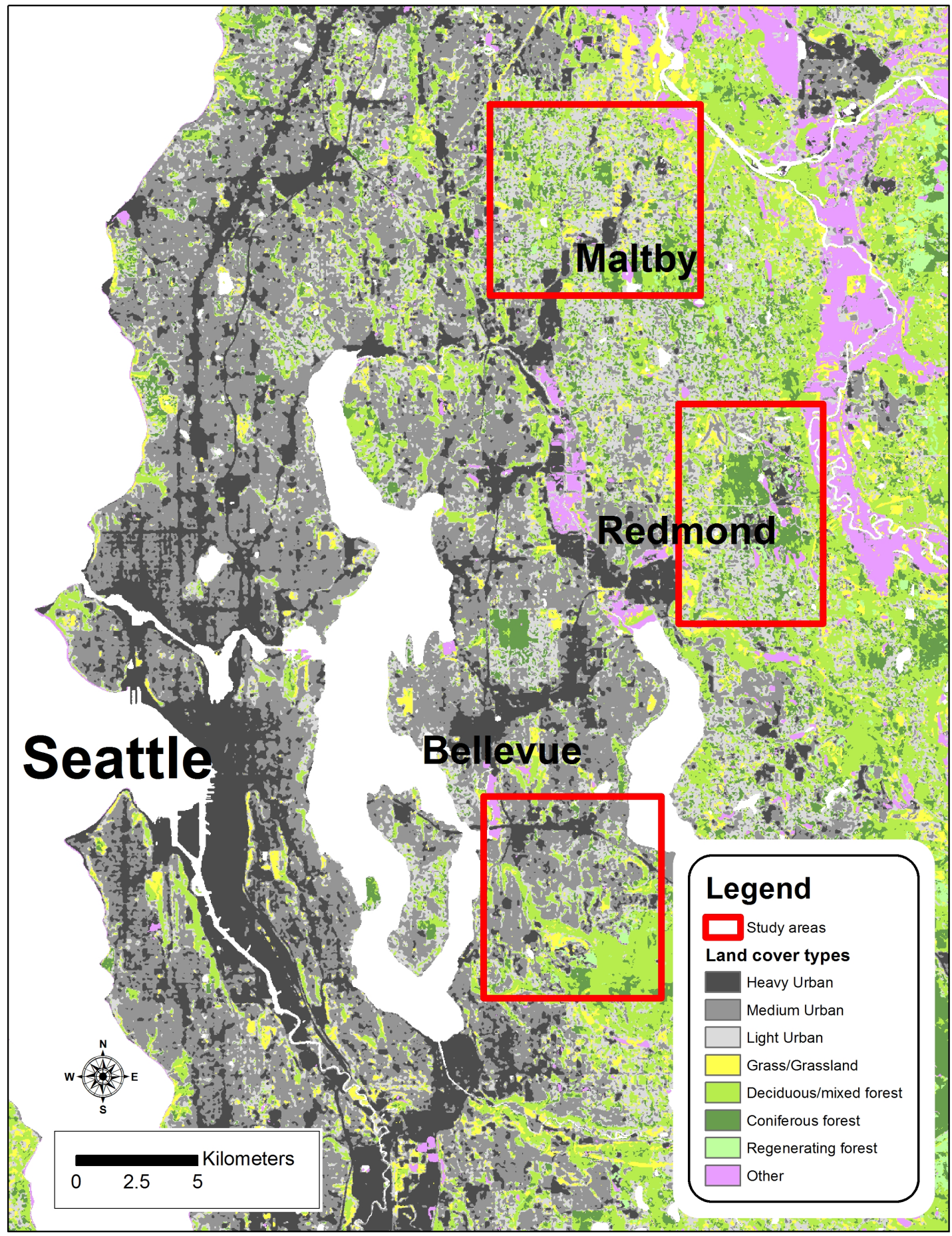


Appendix 2. Relationships between landscape variables (in terms of area or percentage within the home range) and the average number of Pileated Woodpecker chicks fledged between 2009 and 2013 in the study area.

\begin{tabular}{|c|c|c|c|c|c|c|}
\hline \multirow[b]{2}{*}{ Variable } & \multicolumn{3}{|c|}{ Parameter } & \multicolumn{2}{|c|}{ Regression } & \multirow[b]{2}{*}{$p$} \\
\hline & Estimate & Std Error & $\bar{t}$ & Adj R-sq & $F 1,7$ & \\
\hline \multicolumn{7}{|l|}{ Area } \\
\hline Coniferous & 0.0006 & 0.006 & 0.1 & -0.14 & 0.01 & 0.92 \\
\hline Deciduos/mixed & 0.0035 & 0.008 & 0.42 & -0.12 & 0.17 & 0.69 \\
\hline Regeneration forest & 0.0061 & 0.029 & 0.21 & -0.14 & 0.04 & 0.84 \\
\hline Grassland & 0.0224 & 0.018 & 1.24 & 0.06 & 1.55 & 0.25 \\
\hline Ligh & 0.0056 & 0.005 & 1.03 & 0.01 & 1.06 & 0.34 \\
\hline Medil & -0.0019 & 0.007 & -0.3 & -0.13 & 0.09 & 0.77 \\
\hline Heavy & -0.0016 & 0.022 & -0.07 & -0.14 & 0.01 & 0.95 \\
\hline Other & -0.0889 & 0.05 & -1.78 & 0.21 & 3.16 & 0.12 \\
\hline \multicolumn{7}{|l|}{ Percentage } \\
\hline Coniferous & 0.0051 & 0.021 & 0.24 & -0.13 & 0.57 & 0.82 \\
\hline Deciduos/mixed & -0.0072 & 0.041 & -0.18 & -0.14 & 0.03 & 0.87 \\
\hline Regeneration forest & -0.0463 & 0.096 & -0.48 & -0.11 & 0.23 & 0.65 \\
\hline Grassland & 0.1087 & 0.078 & 1.4 & 0.11 & 1.95 & 0.21 \\
\hline Light Urban & 0.029 & 0.027 & 1.07 & 0.02 & 1.15 & 0.32 \\
\hline Medium Urb & -0.0106 & 0.017 & -0.62 & -0.08 & 0.39 & 0.55 \\
\hline Heavy Urban & -0.0215 & 0.078 & -0.28 & -0.13 & 0.08 & 0.79 \\
\hline Other & -0.3254 & 0.714 & -0.46 & -0.11 & 0.21 & 0.66 \\
\hline
\end{tabular}

